\title{
Un/Controlling Desire, Becoming Others Negotiating Justice in the Hong Kong Milieu of Mainland Pregnant Women Influx
}

\section{Man-Chung Chiu}

Department of Law and Business, Hong Kong Shue Yan University, Hong Kong, China.

Email: mcchiu@hksyu.edu

Received May $18^{\text {th }}, 2012$; revised June $17^{\text {th }}, 2012$; accepted June $28^{\text {th }}, 2012$

\begin{abstract}
In the article, I attempt to construct a singular perspective of justice by comparing different paradigms of justiceRawlsian philosophy, Buddhist ideology and Deleuzean theory in the context of Hong Kong where there has been increasing resistance among local people against the influx of Mainland pregnant women, who are regarded as outsiders depriving the local community the much needed local (medical) resources.
\end{abstract}

Keywords: Justice; Law; Desire; Identity; Fairness; Bija; Becoming

\section{Introduction}

Since March 2011, the increasing number of Mainland pregnant women using Hong Kong obstetrics services has ignited/surfaced the continuing (yet implicit) conflict between Mainlanders and HongKongers. ${ }^{1}$ The tension started with the competition for the medical facilities, and now extends to many other facets of lives including social welfare and housing; hence, a binarism of "Mainlanders/Locust vs. HongKongers /Dogs" ${ }^{2}$ develops fast and strong in mass media and internet. In this article, I attempt to construct a philosophical perspective by which justice can be created and engineered in this context by comparing and engaging three philosophical paradigmsRawlsian justice, Buddhist equality and Deleuzean becoming. I argue that the three philosophical perspectives interact with different views on desire and identity; it is also through desire and identity, three philosophical perspectives engage with each other and are sensitized towards each other's weak point: while Rawls proposes a very well structured set of principles in producing procedure so as to settle conflicts justly, caused by different life plans, which are the realization of different desires, both Buddhism and Deleuzean philosophy ask critically respectively if it is possible to devise a discursive identity

*Special thanks go to Professor Lawrence Lau of Fudan University, Shanghai for his valuable advice for the initial draft of this paper.

${ }^{1}$ The number of Mainland pregnant women giving birth in Hong Kong has risen from 27,000 in 2007 to 40,000 in 2010 (HK Liberal Studies, available at: http://www.hkliberalstudies.com/modules/question/index. php?pa=viewads\&lid=27).

${ }^{2}$ For details of the related debate, please see the "Conclusion". and machine of justice creation. However, then can Buddhism and Deleuzen theory, which contradicts each other with respective views on desire, develop a positive step by step guideline, like what Rawlsian formulae do, to release the current intensifying tension soonest? In this article, I will discuss the possibility of developing a way through which three paradigms can cooperate, in the context of the Mainlanders vs. HongKongers clichotomy.

Let us start with the introduction of the conflict.

\section{Production and Intensification of "Mainlanders vs. HongKongers" Binarism}

The recent conflict between Mainlanders and HongKongers started in March 2011, when the influx of Mainland pregnant women (whose husbands can be either residents or non residents of Hong Kong) seems depriving the Hong Kong mothers-to-be of the opportunity to enjoy the medical service provided by Hong Kong local hospitals. ${ }^{3}$ Hong Kong SAR Government, in order to deal with the intensifying discontent among locals, formulate a few policies: 1) Increasing the cost: Raise the obstetrics

${ }^{3}$ K. Wu, "Great Expectations in Hong Kong," 2011, China Daily 11 March, H4. According to a report, "A local man, whose mainland wife is due to give birth in November [2011], still cannot find an obstetric bed in Hong Kong [in July 2011]...The husband said that in the past few months he had contacted all 10 local private hospitals with maternity series and more than 30 doctors in a bid to secure a bed. 'All of them say they can't help us, some can only put us on a waiting list, but they say the chance is slim,' he said." (F. Tam and E. Lee, "Mainland wives rush to book hospital beds," 2011, South China Morning Post 21 July, CITY3) 
package fee for non-local pregnant women on 4 March $2011 ;^{4}$ 2) Setting a quota: Starting in March 2011, Hong Kong public hospitals had stopped taking non-local pregnant women until the end of 2011. In April 2011, the Hong Kong SAR Government agreed to put a cap on the number of non local pregnancy cases at 88,000 per year. ${ }^{5}$ In May, 2011, the government set up a working group to determine the number of births public hospitals can handle every year; 3) Issuing Booking Confirmation Certificate: After the government had urged the private hospitals to reject doctors if they were found issuing the booking confirmation certificate ${ }^{6}$ to non-local pregnant women before they came for assessment, the government then decided to centralize the issue of certificate; and new guidelines were issued-women whose pregnancies do not look normal will not be allowed to labor in Hong Kong; ${ }^{7}$ and 4) Tighten the border control: Mainland pregnant women without relevant documents (for instance: Confirmation Certificate) will not be permitted to enter into Hong Kong. Mainland authority have also discouraged the Mainland pregnant women from using Hong Kong medical facilities: 1) The Family Planning Committee of Guangdong Province state that any second child of a first marriage couple, no matter s/he is born in Mainland, will be counted as "additional", i.e. the parents, should they be the civil servants, shall be dismissed; ${ }^{8}$ and 2) Xiao-Dan Zhu, the Governor of Guangdong Province, stated in March 2012 that the agency who arranged the Mainland pregnant women arriving at Hong Kong would be cracked down. ${ }^{9}$

\footnotetext{
${ }^{4} \mathrm{Wu}$, supra note 3 . The Hong Kong SAR Government in fact had already started a booking system for non-local pregnant women in February 2007: they are required to pay HK\$39,000 when they made the appointment; the Hospital Authority would then issue them a booking confirmation certificate and only with that certificate, the non local pregnant women (including Mainland pregnant women) can cross the border. For those used the facilities in Hong Kong hospital without prior booking - in theory, they could not cross the border - they would have to pay HK\$ 90,000. The court, in Fok Chun-wa v. The Hospital Authority and The Secretary for Food and Health FACV 10/2011, para 33 , held that, although the policy is discriminatory against mainlanders, since status of residence is not part of the core human right values, such policy is legitimate especially in the context where resources are limited. (para. 77).

${ }^{5}$ D. Chong, "Border block urged to ease birth pains for hospitals," 2011 Hong Kong Standard 6 April, P7. But the doctors working in public hospitals suggested a more rigourous measure: all pregnant mainlanders whose husbands are not Hong Kong residents, should be banned from using Hong Kong obstetrics service. (D. Chong, "Hospitals face birth caps to combat mainland rush," 2011, Hong Kong Standard 7 April, P6) But, Mr. Chun-ying Leung, the Chief Executive-elect on 16 April 2012 announced that there will be "zero quota" for pregnant mainland women whose husbands are nonresidents' starting in 2013. ("Doors shuts on moms," Hong Kong Standard 17 April 2012).

${ }^{6}$ Y. H. Ng, "HK to tighten checks on mainland mums," 2011, South China Morning Post 29 April, EDT 3.

${ }^{7}$ See also Fok Chun-wa v. The Hospital Authority and The Secretary for Food and Health FACV 10/2011, para. 33.

${ }^{8} \mathrm{Wu}$, supra note 4.
}

While no one knows if the policies can work effectively, the influx of mainland pregnant women has already given rise the "anti-locust" campaign — a campaign initiated by a group of Hong Kong netizens. They raised fund for a front page advert in newspaper to criticize Mainlanders who visited Hong Kong, claiming that they, like locust, are swamping Hong Kong resources. ${ }^{10}$ Also, according to Yung Jhon, one of the organizers of the campaign, Hong Kong residents were also unhappy with the usage of simplified Chinese characters in Hong Kong and the way Mainlanders "splash" their cash on the local property market, leading to record high property price and rental rates. "The "anti-locust" advertisement, entitled "HongKongers have had enough", appeared on 25 January 2012, in Apple Daily, one of the best selling newspapers in Hong Kong.

In response to the accusation, some Mainlanders argue: "We are not eating on Hong Kong's welfare money. To the contrary, we boost local consumption in Hong Kong and our children might help solve the aging problem it's facing." $" 12$ It seems so true as the private hospitals earn approximately HK\$ 1 billion each year from serving the Mainland pregnant women. ${ }^{13}$ The editorial of South China Morning Post wrote: "Given the birth rate here [i.e. Hong Kong] is among the world's lowest, there is a strong case for better accommodating mainland mothers by expanding the capacity of our obstetric services in private hospitals in the longer term." It also reminded us that Hong Kong's medical service was identified by the Hong Kong SAR Government as one of the six pillars for the future economic prosperity. ${ }^{14}$ It is in this context the following question is asked: "How can Hong Kong, with such a low birth rate, supported with government policy to develop the medical industry including a reputable hospital system, not provide sufficient beds for local mothers or mainland mothers with local husbands?"15

\footnotetext{
9"Hong Kong requests China to halt influx of pregnant women," available at: http://www.panarmenian.net/eng/news/91984/

${ }^{10}$ A. Lee, "Internet abuzz with 'anti-locust' front-page ad drive," 2012, South China Morning Post 26 Jan, CITY1.

${ }^{11}$ V. Chow, "Anger at mainlander visitors escalates with 'locust' ad," 2012, South China Morning Post 1 February, CITY1.

${ }^{12} \mathrm{Wu}$, supra note 8.

${ }^{13}$ Chong, supra note 5 . The debate with regard to resources becomes keen when a mock advertisement was uploaded on 26 January 2012 in the internet forum, saying: "Because you [Hong Kong] are a son, Father [Mainland China] gives you 210 billion yuan a year"; in response, another internet mock advertisement, titled "Reply from your neighbour", said: "If the father is giving 210 billion yuan to the son as pocket money, then the son is paying the father an allowance of 680 billion yuan". For details, please see Chow, supra note 11.

14“"Golden Opportunity for Medical Sector," South China Morning Post 18 December, EDT12.

${ }^{15}$ S.C. Song, "Who Causes the Hospital Beds Shortage for Local Mothers?" 2012, China Daily, 19 January, H3.
} 


\section{Rawlsian Justice: Rationalizing Desire, Devising Justice}

Should we argue that the tension between Mainlanders and HongKongers originates from the competition between Mainland pregnant women and the HongKongers with regard to the medical resources of Hong Kong, it is in fact a conflict of desires - the desire to have easier access to Hong Kong resources available currently? Assuming the resources are limited, Rawlsian theory, "the strongest theory of political justice we have" in relation to resource distribution $[1],{ }^{16}$ seems to be able to provide a quick-fix to the question. ${ }^{17}$

Rarely does the discussion with regard to Rawlsian justice put the emphasis on desire, but when the concepts of good and life plan (which are devised to accommodate different choices and priorities of goods) are put in focus, we will find that how different individual desires can be regulated by the procedure is in fact what Rawlsian theory aims at achieving [3] - the key is not what one person chooses, according to her/his desire, but how s/he chooses [4]. From the Rawlsian point of view, if desire is not rationalized, it will create problems and intensify existing conflicts. Desire, after rationalization, becomes and is termed "good", as it can improve people's life quality [5]. ${ }^{18}$ That also explains why Rawls has to assume that the human subject's nature must be free (i.e. no one owns anyone) ${ }^{19}$, equal (in terms of power and capacities; this notion of equality leads to the criticism of hierarchy), rational (i.e. everyone can seek to maximize one's self interest by forming social contract and facilitating social cooperation), ${ }^{20}$ and reasonable (only if a person is reasonable, s/he can respect each other's interests, i.e. realizing the principles of reciprocity and mutuality); ${ }^{21}$ because only with such human nature, desire will and can be put under control, and individual life plans could be regulated and accommodated by principles and related procedures. Put simply, desire would not then disturb the social co-operations and intensify any existing and pos-

\footnotetext{
${ }^{16}$ Please note: according to Rawls, his theory cannot be applied in private zone of life. For details, please see Rawls [2].

${ }^{17}$ In the context of mainland pregnant women's influx, it is commonly believed that there is a limitation of medical services resources in Hong Kong; for example, Judge Ma, in Fok Chun-wa v. The Hospital Authority and The Secretary for Food and Health FACV 10/2011, writes: "In the public sphere, financial resources are limited and decisions have to be made by the Government as to how Hong Kong's finite resources are to be utilized...Manpower resources are also finite: there is no limitless supply of professional or skilled people." (para. 10).

${ }^{18}$ See also Yao, supra [4], p. 148.

${ }^{19}$ Nussbau, supra [1], p. 28.

${ }^{20}$ Lin, supra [5], p. 6.

${ }^{21}$ Yao, supra note 18 , pp. 5-7. Rawlsian assumption of human subject is always under criticism - as Martha Nussbaum points out: Rawlsian notion of human subject excludes people who are mentally and physical challenged; and Rawlsian version of equality is blind towards the unequal distribution of authority and opportunity (See Nussbau, supra note 19 , pp. 29, 31).
}

sible conflicts.

Rawls also assumes that everyone can put herself/ himself into the position of others. ${ }^{22}$ A Rawlsian human subject also has the capacity for a sense of justice; and a capacity for a conception of the good $;^{23}$ in other words, everyone would 1) accept and understand that the others also accept Rawlsian justice; and 2) believe that social institutions can help realize justice. ${ }^{24}$

Rawlsian principles of justice start with fairness and are developed with Rawls's faith in social contract tradition, ${ }^{25}$ "with its emphasis on mutual advantage as the goal of social cooperation". ${ }^{26}$ Therefore, to Rawls, society is "a cooperative venture for mutual advantage": ${ }^{27}$ From this philosophical paradigm, Rawls develops a set of principles through which desire can be regulated and thus justice can be created: 1) "[E]ach person is to have an equal right to the most extensive basic liberty compatible with a similar liberty for others"; and 2) Social and economic inequalities are acceptable if they are arranged (a) to the greatest benefit to the least advantaged, and (b) attached to the "offices and positions open to all under the conditions of equality of opportunity". ${ }^{28}$ According to Rawlsian principles and related procedure, hence, even though inequality is preordained, when it is accepted by the marginalized powerless in a society, it becomes positive and productive. In other words, Rawls's proposal can prevent inequality from being gross and extreme, and is able to construct hopes for the socially marginalized [6]. Please note: The above principles exercise in a lexical order.

Therefore, according to Rawls, if social institutions (including law and medical services) can formulate sets of procedures, following his principles, then justice can be produced even when there are conflicts, created by different regulated individual desires and related rational plans of life. ${ }^{29}$ Hence, an ideal social cooperation (law making institutions, law enforcement and hospitals), according to Rawls, devised to solve the conflicts, should be conducted by rules and procedures, which are accepted by the public. ${ }^{30}$

\section{Rawlsian Perspective on Law and Justice}

In sum, what Rawls aims to construct ultimately by devising the principles is a set of "correct" procedures; as he believes that only through which, a correct outcome-

\footnotetext{
${ }^{22}$ Chow, supra [3], p. 193.

${ }^{23}$ Rawls, supra [2], p. 302.

${ }^{24}$ Yao, supra note 21, p. 7

${ }^{25}$ Nussbau, supra note 21, p. 11.

${ }^{26}$ Nussbau, supra note 25 , p. 58.

${ }^{27}$ Rawls [7].

${ }^{28}$ Rawls, supra note 27 , pp. 60,83

${ }^{29}$ Chow, supra note 22, p. 188.

${ }^{30}$ Rawls, supra note 28 , pp. 62,95 .
} 
justice and fairness - can be guaranteed in a society. If justice is the most important value for society and social structures, including law [8], ${ }^{31}$ it is hence not surprising when Peter Feng said: it is the duty of law to guarantee the realization of justice [9]. ${ }^{32}$ Amartya Sen also points out:

...John Rawls's right celebrated approach of "justice as fairness" yields a unique set of "principles of justice" that are exclusively concerned with setting up "just institutions"...while requiring that people's behavior complies entirely with the demands of proper functioning of these institutions [10]. ${ }^{33}$

Rawlsian theory is well accepted by Hong Kong Judiciary_Judge Geoffrey Ma, the Chief Justice of Hong Kong since 2010 , offers a very clear definition of justice in the context of Hong Kong:

Justice requires that no one is above the law; in other words, equality. Justice also requires that an individual's rights and liberties must be protected even as against what may be the views of majority of the public [13].

Analysing the conflict between Mainlanders and HongKongers from the Rawlsian perspective, we can ask: Does the influx of Mainland pregnant women really deprive Hong Kong pregnant women of the opportunities to use the local medical services? Would the new law and regulation negatively affect the opportunity of Mainland pregnant women using Hong Kong medical facilities? Would the new law and regulation benefit the least advantaged group? Would the new law and regulation guarantee that everyone can enjoy the opportunity in terms of medical services? However, there are a few questions that we need to tackle before we can answer the above questions: Are Mainlanders and HongKongers coming from the same society? If both groups cannot share the same view on justice and social institutions (including law and medical services), then is it possible for them to form a social contract with mutual advantages? If the answer is no, then another question arises: can the Rawlsian formulae of justice work between societies, when there is a (power) difference? ${ }^{34}$

\section{Mahayana Buddhist Schools of Vijanamatra and Vinaya-Discipline: Going beyond Desire, Constructing Justice}

Justice, under Buddhism, like Rawlsian theory, also starts

\footnotetext{
${ }^{31}$ Yao, supra note 24, p. 2.

${ }^{32}$ This view is further elaborated by Brian Barry, he writes: legal institutions (including law making organization, law enforcement agencies, law courts, law schools and prisons) "are obviously key to the realization of social justice". Barry, supra [8], p. 17.

${ }^{33}$ Whether there is any essential and natural relationship between law and justice always brings keen debate: Costas Douzinas and Ronnie Warrington always argue: justice always lies in future and there is a distance between justice and law: Douzinas and Warrington [11]. Jacques Derrida also points out that it is impossible for justice to be present in law: Derrida [12].

${ }^{34}$ Nussbau, supra note 26, p. 19.
}

with the control of desire and pursuit of equality [14]. ${ }^{35}$ When compared to Rawls, Buddhism provides a more detailed analysis of desire. In this article, I will use the classification of desire developed by Shih Chao-Hwei in "Emotional Connection and Desire: A Buddhist Perspective". In the article, Shih Chao-Hwei, agreeing with the Freudian theory [23], believes that there are five basic desires [24]: sight, sound, smell, taste and touch. These desires correspond to five vijnana (consciousness,: visual perception, auditory perception, olfactory perception, gustatory perception, tactile perception - they are the five senses). According to vijnanamatra, the Buddhist psycho-theory [25], besides the five senses, the rest are mano-vijnana (mind-consciousness,), mana-vijnana (egoconsciousness) and alaya-vijnana (storehouse-consciousness,). Samdhinirmocana-sutra [26] states that, the first five elements are the consciousness of the senses which produce the biological human body, and mano-vijnana is responsible for moral determination, value distinction and interconnects body with the external world. Alayavijnana, which always exists and can go beyond the time constraint, ${ }^{36}$ is an unstable and forever changing entity. It "collects and stores the effects or bija (karmic seeds) of experience until they mature and give rise to new experiences [28]." Alaya-vijana, with loaded energy, initiates the mechanism and interaction between the other consciousness and world.

\footnotetext{
${ }^{35}$ In a series of articles, Chiu [15-18], I argue that both Buddhism (with equality as one of the highest principles) and Confucianism (with their emphasis on "self respect") offer two good matching points for Rawlsian theory to engage with Han-Chinese socio-legal culture. As the article is illustrating the assemblage between Rawlsian theory and Buddhist schools of vijnanamatra and vinaya-discipline, I would elaborate more with regard to the infiltration between Confucianism and Rawlsian theory. Among all the primary goods, Rawls always puts the focus on "self respect": Hu [19]. According to Yao, Da-zhi, Rawlsian notion of self respect is (a) self confidence with regard to her / his ability and competence; and (b) a firm belief that her / his life plan, which is rational and recognized by people she/he respects, can be realized and substantiated. (See supra note 30, p.440 and note 31, p. 149.) Also, Rawlsian self respect can only be fully fulfilled in the condition of liberty through one's sense of justice: Li [20]. ${ }^{36} \mathrm{As}$ Shih Hong-xue indicated, Buddhism does not believe end of life means end of everything, and alaya-vijnana works as the linkage between lives: Shih [27]. In contemporary Han-Chinese language, justice is translated as Yi. In Mencius's theory of Yi, Yi comes from human nature [21]. Only through tough and strict training, together with strong will and right understanding of morality, which means respect and maintenance of a hierarchical social structure, a person can understand Yi: see Wan [22] "Life is also something I want, and righteousness is also something I want. If I cannot get both of them, I am one who will do without life and choose righteousness." (Chapter 6A, Mencius) (trans., 生, 亦 我所欲也; 義, 亦我所欲也。二者不可得兼, 舍生而取義者也) So what does one have to learn and be trained in order to understand Yi? It is the feeling of shame and dislike; i.e. morality: The feeling of shame and dislike is the principle of righteousness. (Chapter 3A, Mencius) (trans., 差惡之心，義之端也) Although Rawlsian theory is a product of liberalism, and Mencius does not use the term 'self-respect' and his theory is not developed in the condition of liberty, and the requirement of seeking respect from people is the common point shared by the theories, and thus self respect can be a matching point to facilitate the osmosis of Rawlsian theory with Han-Chinese culture.
} 
The assemblage of eight vijnana, in short, engineers the concepts of identity and world. ${ }^{37}$ The interactive dialogue between the eight consciousnesses and the world also constitutes the karmic bija, which are stored in alaya-vijnana, determines the upcoming interaction between the consciousnesses and the world. Since karmic bija is the carrier of desire [29], desire takes part in the construction of world and human subject. The assemblage between body and the external world then re-create the karmic bija/desire which would simultaneously reload alaya-vijnana. This machine is called alayapratitya-samutpada (Dependant-arising of Alaya-vijnana,), which means the mental constitutive reception of every activity and phenomenon can never be a fixed essentiality, but a virtual illusion re-created by the interaction of karmic bija/desire under a particular condition and milieu, which is also a product of karmic bija exercise and karma. This line of argument leads to the development of an important Buddhist principle: anātman (Non-Insistence or Self-less-ness,). "Self" in this context does not only mean "I", but over-insistence of a perspective [30]: $:^{38}$

The Buddhist Path of anatman holds that there is neither soul nor any essential form that constitutes a human being...Secondly, anātman is not a denial of self as person but denial of self as self-centredness...the goal of anätman is to detach from our egocentricity in order to realize the interdependence and interconnectedness of all beings, sentient and insentient [31].

The principle lays the theoretical foundation of another significant principle in Buddhism, i.e. anitya (Non-Permanence,), which means there is no eternality in the world: Since the composition of karmic bija/desire keeps on changing, it is impossible to have any monolithic and universal perspective; and if the world, the related activities and phenomena are vijnana/psycho products, initiated by a set of karmic bija/desire and end up with the production of another cluster of karmic bija/desire, then a metanarrative or grand narrative is also only another virtual illusion. The three principles, "Dependant-arising of Alaya-vijnana", "Non-Insistence" and "Non-Permanence", inevitably manufacture the Buddhist notion of justice/equality:

Within my Dhamma, the 4 clans-1) priestly, 2) military and ruling, 3) farmers and traders, and 4) serfs...would all drop their original titles and are called "Shih" students of Buddha. ${ }^{39}$

Since the differences among people are formatted by different combinations of karmic bija/desire, subject/ being and value judgments are not any pregiven, precon-

\footnotetext{
${ }^{37}$ Shih, supra note 36 , p. 70.

${ }^{38}$ Different schools of Buddhism have different definitions of 'I': 'I' can mean the subjectivity of samsara, multitude or unchanged self. For details, please see Chen, supra [30], pp. 785-787.

${ }^{39}$ Taisho Tripitaka Editorial Committee, 1985, Chapter 22 (大正新修大 藏經·四分律).
}

ditional and fixed concepts, but becoming. In other words, while differences exist, they do not and should not be any foundation or justification of hierarchical discrimination/inequality, as differences and identities are only temporary or a stage of becoming. As Li-Tian Fang points out, going beyond any insistences and related desires, accepting differences and producing equality are the ultimate goals of Buddhist practice [32].

The Buddhist machine/pursuit of equality is however hindered by mana-vijnana, which ignores tathata (the ultimate truth) and keeps on insisting self and self perspective. ${ }^{40}$ Due to the exercise of mana-vijnana, two kinds of negative desire/attachment emerge: the desire to grasp an (illusory) "I" (for example: an authentic HongKonger) and the desire to grasp an (illusory) object (for example: the Hong Kong resources) [34]. With these two attachments, distinctions/discriminations arise (for example: "you are an un-civilized Mainlander, you must not come and steal Hong Kong resources, created and contributed by us"). Only when insistence of fixed identity/subject and the attachments (the desires to grasp) are gone beyond, would there be a Buddhist world of justice and equality. ${ }^{41}$ Buddhism therefore advocates that we need to start with controlling desire, and at the end of the day, we have to go beyond all desire. ${ }^{42}$

Vijnanamatra does not only provide a detailed description on how the psycho-mechanism works, it also portrays the picture where justice/equality is achieved. Justice/equality, advocated by vijnanamatra, has to start with anātman: it can be achieved by āśraya-paravṛtt (transmutation of vijnana to jnana (wistom)), where vijnana are totally free from any negative desires (for instance, greed) and attachments.

With the rise of wisdoms, people arrive at the stage of parlinispanna-svabhava from paratantra-svabhaava, ${ }^{43}$ and would go over their negative desire and attachments (i.e. insistences) - their own "(insistent) I" (for example, the identity of authentic HongKonger) and the identity-related (insistent) objects (Hong Kong resources only be used by HongKongers), and start critically reflecting the social rules developed and advocated by majority and no longer judge the perceptions with reference to them solely. They would also stop desiring and insisting on their worldview as the hegemonic standard (of law) and/or imposing it on others (Mainlanders). With wisdom, human are sensitized to the condition of unjust discrimination where there are less resourceful groups, including the pregnant women who cannot fully enjoy the medical service in Hong Kong (not essentially Mainland/ Hong Kong pregnant women). With the ideological per-

\footnotetext{
${ }^{40}$ See Zhōu, supra [25], p. 8; Chen, supra [30], pp. 121, 129 and Zhou [33].

${ }^{41}$ Shih, supra note 37 , pp. 314-315.

${ }^{42}$ Shih, supra [23].

${ }^{43}$ Zhou, supra [33], p. 303.
} 
spective, which refuses to establish an eternal hegemony, people would start assisting and empowering the powerless (for example, those pregnant women who cannot fully enjoy the medical facilities in Hong Kong), for instance, by drafting and enacting new laws and policies.

The rise of wisdom therefore means the gradual disappearance of negative desires and insistent attachments; i.e., the established layers which come from fixed principles and subjects:

...the contemporary psychoanalytic fascination with self-multiplicity appears to stem at least in part from a desire to challenge monolithic views of mental health that are implicitly conformist in nature. The emphasis in the Buddhist conception of no-self is on decreasing the sense of existential isolation, by emphasizing the constructed nature of the boundary between self and others and the interdependence of all living beings [35].

\section{Mahayana Buddhist Perspective on Law and Justice}

The problem is: how can the āśraya-paravrtt start? According to Mahayana tradition, as Shih Chao-Hwei said, certainly, law and regulation can help us reach that aim. ${ }^{44}$ If we apply and engage the School of vinaya-discipline in developing a jurisprudential perspective, it can definitely help facilitate the transmutation through karmic machine - a machine of choice and responsibility-before the completion of āśraya-paravrtt, karma is always a non-stop machine, and the production of karmic bija/desire never ends, as every decision and action of human subject will influence the ever-changing nature of karmic bija. In other words, karmic bija is not a static concept either; it grows with the changes and evolution of contexts - this process is called vāsanā (Fumigation or Perfume) [36]. ${ }^{45}$

In Sifenlu Xingshi Chao, ${ }^{46}$ Dao-Xuan Shih describes how vāsanā happens: since making, studying, understanding, accepting, following and implementing vinaya (for example, law and regulation) is a kind of activity (karma) that happens in the world, activated by bija/desire, those activities themselves have their influences tattooed on the bija which already exist via the exercise of mano-vijnana ${ }^{47}$ - the impact is called the "duṣkṛta-samavara" (vows); i.e. the nature of the bija affected is changed. The process also creates the new bija - those bija which are influenced by the vinaya will then be stored in alaya-vijnana and will re-create and reformat the human subject through the exercises of the other vi-

\footnotetext{
${ }^{44}$ See Shih, supra note 42 , pp. 86,88 .

${ }^{45}$ Please note, however: not all karmic bija can be perfumed - if they are already affected negatively and very insistent, they can't be reformated; and then some karmic bija can be reformatted by later activities; i.e. they may be perfumed by positive action, but later by negative activities. For details, please see Chen, supra note 40, pp. 443-444.

${ }^{46}$ Taisho Tripitaka Editorial Committee (1985), Chapter 40.

${ }^{47}$ Chen, supra 45 , p. 445.
}

jnana. ${ }^{48}$ Since the vinaya can have substantial effect on bija, then they can certainly play a vital role in the àśraya-paravrtt-provided that the vinaya can facilitate critical investigation of world and introduce the Buddhist ideologies of justice/equality, then by making and following the vinaya, âśraya-paravrtt can start and proceed; and when the àsraya-paravrtt is completed, vinaya can in turn be enacted, interpreted and implemented by jnana. And, from that perspective, by following and implementing such vinaya, more people can fulfill and complete the âsraya-paravrtt and, through the interaction between Buddhists and law and regulation, justice/equality can be further realized. ${ }^{49}$ Buddhist legal philosophy, developed by the school of vinaya-discipline, hence produces a jurisprudential machine by which justice/equality can be constituted, it also sensitizes us to the multiple subjects - due to the karmic mechanism of bija, desires and related insistent attachments are becoming impossible. Different and ever-changing concepts and formulae of justice can therefore be accommodated and accepted.

In short, the schools of vijnanamatra and vinaya-discripline would support and confirm the view of Peter Fen, Brian Barr and Amartya Sen on the connection between vinaya/law and justice: law is definitely essential for and can help enhancing the transmutation of vijnana to jnana [37] and thus promote the construction of equality and interpretation of justice. ${ }^{50}$ Buddhism goes one step further than Rawlsian theory when discussing the function of law: law does not only set up a procedure where conflicts can be settled justly, a just law can in fact help human to change the nature of desire and insistence and thus eliminate all conflict, possibly forever. The Buddhist schools of thought also pose a challenge to Rawlsian theory-there are no fixed principles of justice production, since there is a lack of permanence-everything can be changed - if there is a change of context (for example, the least advantaged becoming the powerful), would Rawlsian theory still function perfectly? Also, there is no natural and monolithic definition of "least advantaged group" and equality, as the identity is always changing due to the changing nature of bija combinations; and because the identity cannot be fixed, there is no ground and justification for any kind of discrimination and hierarchies. When dealing with the conflict of Mainlanders and HongKongers in the context of medical services, then, from the perspective of vijnanamatra and vinaya-discipline, we should ask: should any policy and regulations controlling the influx of Mainland pregnant women treat Mainland and Hong Kong pregnant women differently and thus set up a cap on the number of Mainland pregnant women?

\footnotetext{
${ }^{48}$ Chen, supra 47, p. 112.

${ }^{49}$ Yang, supra [36], p. 114

${ }^{50}$ Shih, supra [37], p. 105.
} 


\section{Deleuzean Machine of Justice: Becoming Least Advantaged Group}

Deleuze has a very different understanding of desire: while Buddhists have different and multiple classifications and definitions of desires, Delezue, like Nietzsche, believes that desire, being the instinctive, elementary, original and authentic, is the greatest power of life [38]. ${ }^{51}$ He hence always stresses the "positivity" and "productivity" of desire [39]: Deleuzean desire, with such power and energy, plays an important role in the creation of subjects. A subject (including justice, law and identity) is always a product of connections, disconnections and reconnections, which are parts of a machine, ${ }^{52}$ driven by different assemblages; and are formulated by two lines of forces-desire and social force (including law courts, legislature, NGOs, hospitals and media). ${ }^{53}$ Deleuze argues that the social force always wants to capture and regulate desire, which provides the energy for the exercise of assemblage, ${ }^{54}$ and fixates a subject, through repetition and codification. As a result, certain procedures and qualities are read as universal marks ${ }^{55}$ - this process is territorialization (for example, Mainlanders are labeled as the robber of Hong Kong limited resources) [44].

Territorialization does not nonetheless signify the end of subject creation-Deleuzean desire cannot be eternally controlled by molar lines of social force: lines of desire are multiple and contested - there are always simultaneously different/new types of desire (the desire of giving birth to babies in Hong Kong may not be very popular among Mainlanders before 1970s) and thus social force (for example, new laws and new institutions) [45]; so, (new) machines, driven by different forces, can connect, disconnect and reconnect with other machines; one machine can never be reduced to any singular connection, i.e. machines are always fluid and dynamic. ${ }^{56}$

Deleuze argues that the molar lines of social forces are rhizomatic and thus lack an origin or a centre, and molecular lines of desire cannot be predicted, then subject can only be multiple [46]. Hence, it is not surprising that deterritorialization initiated by desire and the lines of flight are always created at the weaker edge of the rhizomatic matrix, where challenges coming from desire that fuels the lines of flight, can easily take place [47].

\footnotetext{
${ }^{51}$ L. De Bolle, "Desire and Schizophrenia," 2010, in [38], p. 8.

${ }^{52}$ As Claire Colebrook illustrates: a machine is "nothing more than its connections". See Colebrook [40].

${ }^{53}$ According to Deleuze, while the social force are always sementary and rigid; desire flows freely and preexists human. As Claire Colebrook writes: "Life is a flow of desire." (Colebrook, supra note 52, 142). Jun [41]; Deleuze \& Felix [42]. It seems desire is the key drive of machine: "It is axiomatic for Deleuze and Guattari that no technical machine can exist without the prior investment of desire." (Buchanan [43]).

${ }^{54}$ De Bolle, supra note 51, p. 17.

${ }^{55}$ Colebrook, supra note 53, p. 45.

${ }^{56}$ Jun, supra note 53, p. 351.
}

Along with the deterritorialization, the process of becoming starts and never ends.

Deleuze thus advocates that every concept/identity is always a "becoming". But, as Damian Sutton and David Martin-Jones point out, reterritorialization always happens, especially when the force of the deterritorialization and the desire that drives it is not strong enough. So, becoming, as Levi Bryant said, would always contain contradictions and oppositions [48]; as lines of flight always take off after de/territorialization, with the emergence and influx of different desires. ${ }^{57}$ In other words, any effort to fixate a subject (like Hong Kong people as the victim of the swamp of resources) or develop a universal and timeless formula for justice (like what John Rawls did), are doomed to be a failure - this echoes with Buddhism-deterritorialization always produces resistance which challenges the formula, although such resistance may not always be strong enough to subvert it.

As elaborated by Ian Buchanan: Deleuzean desire therefore always sows the seeds of revolution as it always tries to elude the coding imposed by lines of social forces. ${ }^{58}$ Deleuzean notion of justice must be able to release desire; because only through which, all "attempts to ground any reasoning, rationale, or logic on some object measure" would be destroyed and torn off [50]. In other words, according to Deleuze, justice would only be created when becoming and deterritorialization happen, where all layers and connections are broken by line of flights, initiated by the liberation of desires. This paradigm of justice, as Jami Weinstein puts, will evoke better concepts to resolve the problems to which any attempt of developing a monolithic formula of justice was originally linked [51]. But Loretta Capeheart and Dragon Milovanovic also warn us: moving away from any monolithic formula means moving away from an evaluative standard, which therefore may mean development of unintentionally "negative" consequences. 59

\section{Deleuzean Perspective on Law and Justice}

In other words, as justice is a kind of becoming, created by different lines of desire and social institutions (social control and law), it is impossible to develop and devise an ahistoric notion of subject and an acontextual formula and procedure of justice construction (like Rawlsian principles). Further, since Deleuzean desire has a very different definition, not only does it mean desires cannot be listed exhaustively, like what Rawlsian list of good tries to do, Deleuzean would not aim at controlling or going beyond desire, like what Buddhists and Rawlsians advocate, but activating desire so as to generate polylithic lines of flight, that can activate deterritorizations,

\footnotetext{
${ }^{57}$ D. Smith, "Introduction," 1997, in [49], p. xlv.

${ }^{58}$ Buchanan, supra [43], p. 45.

${ }^{59}$ Capeheart and Milovanovic, supra [50], p. 135.
} 
through which the existing layers and differences (and related discrimination) will be destabilized and challenged. In the case of Mainlanders and HongKongers conflict, a Deleuzean will argue the existing desire (for example the request of more medical services, the desire of having better and more effective Mainland social institutions, and the mutual discrimination between HongKongers and Mainlanders) have successfully initiated the drive (another new desire) to revise, and improve the existing social cooperations (between institutions and between Mainlanders and HongKongers), for example, better possible allocation of medical resources, revision of birth control policy and Race Discrimination Ordinance. ${ }^{60}$ In short, the conflict, generated by clash of different desires, itself is not negative, but productive. However, what Deleuzean theory fails to do is to provide a possible step by step formula to create positive and productive changes in the process of destabilization and constructing a positive strategy, and there may be undesirable and unforeseeable consequences - of course, as Deleuzeans argue, it is impossible to devise an one for all solution, because justice is only a becoming, and any wrong will and can be corrected as desire will keep on arising and changes/revisions will be brought.

\section{Conclusion: Dialogue among Rawlsians, Mahayana Buddhists and Deleuzeans in the Milieu of Justice}

It seems Mahayana Buddhist philosophy and Deleuzean theory are not compatible with each other: (Mahayana) Buddhism assumes that desires could bring negative effect, i.e. the negative desires, like greed, and thus have to be put under control; Deleuze believes that it is good to have new and emerging desire. However, in fact, both share a number of commonalities, especially when critically investigating Rawlsian theory: 1) desires are multiple, thus it is impossible to have an exhausted list of desire, for example: the Rawlsian list of good - for Mahayana Buddhist, whenever there are bija, there can be desires; and for Deleuzean, desires always exist and keep on generating; 2) not everyone is totally free, like what Rawlsians claim - for (Mahayana) Buddhists, no one can escape from karma machine (before transmutation); and for Deleuzean, human subjects are always the product of machines, driven by multiple and diversified lines of desire and social control. Mahayana Buddhism and Deleuzean philosophy also share two views: 1) there are no

\footnotetext{
${ }^{60}$ Cap 602 LHK. People once argued that the Ordinance should be used to stop the publication of anti-locust advertisement as it is obviously a racial vilification (Section 45), which is illegal. Equal Opportunities Commission of Hong Kong clearly stated that as Mainlanders and HongKongers belong to the same Race (Han-Chinese), any conflict between two groups of people was not racial discrimination. ("It is not Racial Discrimination, just tension between group," (trans., 非種族歧 視僅種群緊張) MingPao 4 February 2012, A8).
}

eternally fixed social layers and-with Buddhist āśraya-paravrtt, inequality and discrimination can be eliminated with the final disappearance of bija/desire; and with the Deleuzean desires and related lines of flight, all existing social demarcations can be challenged; 2) Law is vital-Buddhism believes that law can help go beyond desire, Deleuzean theory believes that law is a product of re/territorialization; aiming to fixate desire; but, of course, this attempt is doomed to be a failure as new desire will gloom deterritorialization and reterritorialization, which means existing laws can be repealed, and new laws can emerge.

Even though Buddhism and Deleuzen philosophy have two very contradictory views on desire, their perspectives on desire, which leads to the multiple understanding of body, expose the major weak point of Rawlsian theory, i.e. it fails to provide a definition of the least advantaged group. In the context of Mainland pregnant women influx, the Hong Kong pregnant women who claimed that their opportunities of using the medical facilities are deprived are the least advantaged, but so are the Mainland pregnant women who desire to use the service in Hong Kong - as they have to spend more than HongKongers and their decisions of coming to Hong Kong is initiated by different desires, including escape from the birth control policy, desire to see their offspring enjoying a more efficient medical, social, education and legal system. ${ }^{61}$ But then, when the vijnana, which composes body, can be transmutated, according to Buddhist vijnanamatra, is it possible to have a fixed identity? This view is echoed by Deleuzean concept of "Body without Organs" (BwO hereafter): because of unpredictable momentum, lines of desire, territorialization and fixation of identities/bodies is never complete, and body cannot be a rigidly ordered entity, but $\mathrm{BwO}$ [52]. BwO, signifies the resistance to any notion of territorialized body that comes with a whole package of organized and hierarchized organs, is a metaphor for the shifting, interconnected, constantly moving and constructed body. ${ }^{62}$ Body therefore keeps on constructing itself. ${ }^{63}$ Using $\mathrm{BwO}$ as the lens of scrutiny, we can then ask: Can we naturalize an identity? Why do we have to prioritize a certain dialect, language, or accent in defining an identity?

So the Rawlsian theory seems to be subverted by Buddhist and Deleuzean theories of justice-people are not free, list of primary goods is not practical and a definition for the least advantaged group is impossible. But it does not mean that the Rawlsian theory is completely

\footnotetext{
${ }^{61}$ As Johnny Mok SC indicates in 'Legal Measures to Address Mainland Births in Hong Kong' Symposium, held by University of Hong Kong on 9 June 2012, the Mainland pregnant women come to give birth in Hong Kong because of the better medical facilities in the social administrative region.

${ }^{62}$ Rajchman, supra [52], p. 267.

${ }^{63}$ Smith, supra note 57, p. xxxxvii.
} 
useless - no one can deny that protection of the peripheral powerless is a good starting point and in order to fix a problem quickly, a clear set of step by step guideline, like Rawlsian theory, especially with its emphasis on equal opportunity, can be an efficient starting point. Yet we have to understand a social contract, which assumes that human subjects are free and there must be mutual advantages, is not possible. So, we should not aim at reaching an agreement that is based on everyone's acceptance of justice; what we should seek is the acceptance and respect of different and changing desires and related changing life plans. This can be achieved by what the Rawlsians advocate: everyone should step into the shoes of the others (especially the least advantaged); but Buddhists and Deleuzeans go further, the former advocate Samata-jnana/Wisdom of Equality, and the latter ask everyone becoming others, and negotiate a way by which the conflict and tension can be settled and solved. In short, justice is no longer simply a set of procedures, as argued by Rawls, but an attitude and perspective by which negotiation between parties can start and continue.

In short, Rawlsian notion of justice fails to address the ever changing desire and thus is not sensitized towards the unstable human identities. According to the perspectives of Mahayana Buddhism and Deleuzean philosophy, justice should be created only when multiple desires are recognized (not simply controlled), and negative desires are changed into the positive ones by, for example, becoming each others, before making relevant laws and policies.

In the case of the influx of Mainland pregnant women, we should no longer question whether the desire of labouring in Hong Kong is right or not, but we should be becoming each other-becoming Mainland pregnant women and becoming Hong Kong pregnant women; and negotiate with ourselves by asking the following questions: Are the resources (in Hong Kong) really limited? Why can't the Hong Kong government spend more on developing medical services as it is one of the pillar industries and the current medical resources available could not even cater to all the needs (not only obstetrics services) of locals? ${ }^{64}$ If the Mainlanders spend so much in Hong Kong, are the resources growing? Is there any way that we can allocate the resources more effectively? In short, we should ask how we feel and what solution we can propose, in every singular context, if we are becoming the party we challenge. And from that starting point, we should ask how equal opportunities can be guaranteed, not only by making laws and regulations, but by reflecting and reviewing existing laws and regulations with regard to new situations (raised by new desires).

\footnotetext{
64“"Hong Kong: Public Hospital Nibbled by Privatization, Grassroot Mainland Immigrants being Blamed," available at:

http://chinaworker.info/zh/content/news/1431/
}

Recently, the dispute between Mainlanders and HongKongers is further intensified by three incidents: (a) Dolce and Gabbana did not allow HongKongers to take photo outside their Hong Kong flagshop in Harbour City, Tsim Sha Tsui, while allowing Mainlanders to do so; this incident provoked more than 1,000 people to gather in front of the shop for two consecutive Sundays ( 8 and 15 January 2012); ${ }^{65}$ (b) Professor Qing-dong Kong titled HongKongers as "running dogs of British Government" in a Mainland television programme, "Kong Monk Has Something to Say", on 19 January 2012, after footage showing a Hong Kong passenger and a Mainland family started quarrelling when the former said the latter should not allow their child to eat in Mass Transit Railway, where eating and drinking were forbidden, was widely shown; (c) A new entry plan for mainland cars, announced by Hong Kong SAR government on 13 February, also fuels the conflict between Mainlanders and HongKongers. According to the scheme, 50 Hong Kong-registered vehicles will be allowed to travel directly into GuangDong. However, HongKongers fear that when Mainland-registered cars are allowed to come to Hong Kong, as the possible phase 2 of the programme, it will bring chaos on the road, as Mainland drivers are "famous" for not obeying the rules:

Our own drivers already have some really bad habits, such as changing lines without signaling, having no respect for pedestrians, and driving aggressively. Such bad behavour is even worse on the mainland. Can we expect these mainland drivers magically to improve once they hit local roads? $?^{66}$

When a protest started in February, 7000 people had made online pledge to join the demonstration. Also, one of the major political parties, Democratic Party, have also collected 1400 signatures protesting the scheme. Raymond Tam, Secretary for Constitutional and Mainland Affair indicated that there is no timeline for phase $2 .^{67}$

Using the revised formulae of justice theory, when dealing with the situations, we will then ask ourselves: 1) What will we feel if we are becoming labeled as "Locust"/“Dog"? 2) Will we be happy if someone does not obey the law and regulations (like eating on trains) in our respective jurisdictions (Mainland or Hong Kong)? 3) If HongKongers are allowed to drive directly to the north of the border, why can't the same apply to the Mainland drivers? 4) What can law do in order to solve the possible problems and conflicts (the desire of making sure every-

\footnotetext{
65" One thousand protest Dolce \& Gabbana Hong Kong store over photo ban," The Telegraph 8 January 2012; "There Are Still Protesters Outside Dolce \& Gabbana's Hong Kong Boutique," New York Fashion 16 January 2012.

${ }^{66}$ A. Lo,"Don't extend welcome to mainland cars," 2012, South China Morning Post 13 February, EDT2.

${ }^{67}$ K. Ip, "Hundreds push to block driving plan," 2012, Hong Kong Standard 13 February, P2.
} 
one obey the law and the desire of not following the traffic law in Hong Kong)? However, please note: as what Buddhist and Deleuzean argue respectively: nothing is permanent and there is always deterritorialization-āśraya-paravrtt and becoming are not any once-for-all formulae of justice or acceptance of difference; the only eternal truth is the non existence of fixation and permanence, and the meaning of justice keeps on evolving.

\section{REFERENCES}

[1] M. C. Nussbau, "Frontiers of Justice: Disability, Nationality, Species Membership," The Belknap Press, Cambridge, 2006, p. 24.

[2] J. Rawls, "Political Liberalism," Columbia University Press, New York, 2005.

[3] P. C. Chow, "Politics of Liberal Equality," Joint Publishing Company, Beijing, 2010, p. 1.

[4] D. Z. Yao, "John Rawls," Changchun Publishing House, Changchun, 2011, p. 10.

[5] H. W. Lin, "Justice and Citizenship," Jilin Publishing Group Limited, Changchun, 2008, p. 32.

[6] D. H. Zhao, "Rawls's Theory of Justice: A Comment," Joint Publication, Hong Kong, 1988, p. 151.

[7] J. Rawls, “A Theory of Justice," Harvard University Press, Cambridge, 1971, pp. 225-241.

[8] B. Barry, "Why Social Justice Matters," Polity, Cambridge, 2005, p. 16.

[9] P. Feng, "Wooden-Legged Justice," Peking University Press, Beijing, 2007, p. 40.

[10] A. Sen, "The Idea of Justice," The Belknap Press, Cambridge, 2009, p. xi.

[11] C. Douzinas and R. Warrington, "The Face of Justice: A Jurisprudence of Alterity," Social Legal Studies, Vol. 3, No. 3, 1994, pp. 405-425. doi: $10.1177 / 096466399400300306$

[12] J. Derrida, "Force of Law: The 'Mystical Foundation of Authority'," Cardozo Law Review, Vol. 11, No. 919, 1990, pp. 921-1045.

[13] G. Ma, "CJ's Speech at Ceremonial Opening of the Legal Year 2011," 2011.

http://www.info.gov.hk/gia/general/201101/10/P2011011 00201.htm

[14] D. M. Engel and J. S. Engel, "Tort, Custom, and Karma: Globalization and Legal Consciousness in Thailand," Stanford University Press, Stanford, 2010, p. 128.

[15] M.-C. Chiu, "Going Beyond Globalization and Localization: Articulating a Theory of Justice in Han-Chinese Culture," Law and Critique, Vol. 21, No. 1, 2010, pp. 93110. doi:10.1007/s10978-009-9061-2

[16] M.-C. Chiu, "Beyond Colonialism: Osmotic Reconstruction of Gender/Sexual Justice," Inter-Asia Cultural Studies, Vol. 10, No. 3, 2009, pp. 399-421. doi:10.1080/14649370902949390

[17] M.-C. Chiu, "A Hybrid of Harmony and Resistance at the
Margin: Legal Discourse of Gender/Sexual Justice in Hong Kong, P. R. China," Journal of Social Sciences, Vol. 35, 2008, pp. 179-201.

[18] M.-C. Chiu, "De/Sexing Law/Fa: Development of an Indigenous Theory of Sexuality Justice in Hong Kong," Hong Kong Law Journal, Vol. 37, No. 3, 2007, pp. 775803.

[19] S. J. Hu, "Political Analysis of Law," Peking University Press, Beijing, 2005, p. 9.

[20] Z. J. Li, "Political Philosophy of Well Ordered Society," People's Publishing House, Beijing, 2009, p. 210.

[21] Y. Ni, "The Concept of Justice in Societal Change," Shandong University Press, Jinan, 2006, p. 3.

[22] G. J. Wan, "Study on Mengzi's Theory of Ren and Yi," Shandong University Press, Jinan, 2009, p. 157.

[23] C. H. Shih, "Emotional Connection and Desire: A Buddhist Perspective," In: M.-C. Chiu, Ed., Chinese Sex (uality)/Gender-Age Machine, Red Publication, Hong Kong, 2011, p. 71.

[24] B. Mukhi, "The Circle of Life Revolved around Avidya, Desire \& Karma," 2011.

http://www.free-news-release.com/The-circle-of-life-revo lved-around-avidya--desire--amp--Karma-Detail_175778. html

[25] S.-J. Zhōu, "Studies of Vijnanamatra," Heavenly Lotus, Taipei, 1998, p. 5.

[26] J. Powers, "Wisdoms of Buddha: The Samdhinirmocana Sutra," Dharma Publishing, Berkeley, 1995.

[27] H. X. Shih, "Vijnanamatra," BaShuShuShe, Chengdu, 2009, p. 75.

[28] J. Koller, "Asian Philosophies," 5th Edition, Prentice Hall, New Jersey, 2002, p. 222.

[29] J. T. Sun, "Psychology in Primitive Buddhism," In: A. Molino, Ed., The Couch and the Tree: Dialogues in Psychoanalysis and Buddhism, North Point Press, New York, 1988, p. 3.

[30] B. Chen, "Buddhist Psychology," Buddha's Light, Taipei, 2007, pp. 795-848.

[31] S. Chan, "Buddhism and Human Rights," In: R. Smith and C. Van Den Anker, Eds., Human Rights, Hodder Arnold, Spain, 2005, p. 25.

[32] L. T. Fang, "Chinese Buddhist Culture," Joint Publication, Hong Kong, 2008, p. 138.

[33] G. H. Zhou, "Vijnanamatra Thoughts: An Introduction to Yogacara Buddhism Volume 1," China Social Sciences Press, Beijing, 2009, p. 13.

[34] R. Epstein, "The Transformation of Consciousness into Wisdom in the Chinese Consciousness-Only School According to the Cheng Wei-Shi Lun," 1985. http://online.sfsu.edu/rone/Buddhism/Yogacara/TRANSF ORMATION\%20OF\%20CONSCIOUSNESS.htm

[35] J. Safran, "Psychoanalysis and Buddhism as Cultural Institutions," In: J. Safran, Ed., Psychoanalysis and Buddhism: An Unfolding Dialogue, Wisdom Publication, Boston, 2003, p. 23.

[36] W. Z. Yang, "A Research of the Nature of Mind of Chi- 
nese Buddhism," Religious Culture, Beijing, 2007, pp. 298-299.

[37] C.-H. Shih, "Differences in the Principles of Monastic Precepts and Law," Studies in Oriental Religions, Vol. 4, No. 6, 1994, pp. 103-115.

[38] L. De Bolle, "Deleuze and Psychoanalysis," Leuven University Press, Leuven, 2010.

[39] D. Goodley, "Becoming Rhizomatic Parents: Deleuze, Guattari and Disabled Babies," Disability and Society, Vol. 22, No. 2, 2007, pp. 145-160. doi:10.1080/09687590601141576

[40] C. Colebrook, "Understanding Deleuze," Allen and Unwin, Crows Nest, 2003, p. 56.

[41] N. Jun, "Deleuze and Normativity," Philosophy Today, Vol. 53, No. 4, 2009, pp. 347-358.

[42] G. Deleuze and F. Guattari, "Anti-Oedipus," Continuum, London, 1984.

[43] B. Ian "Deleuze and Guattari's Anti-Oedipus," Continuum, London, 2008.

[44] N. Rose, "Government and Control," British Journal of Criminology, Vol. 40, No. 2, 2000, pp. 321-339. doi: $10.1093 / \mathrm{bjc} / 40.2 .321$

[45] J. Winslade, "Tracing Lines of Flight: Implications of the
Work of Gilles Deleuze for Narrative Practice," Family Process, Vol. 48, No. 3, 2009, pp. 332-346. doi:10.1111/j.1545-5300.2009.01286.x

[46] S. Linstead and A. Pullen, "Gender as Multiplicity: Desire, Displacement, Difference and Dispersion," Human Relations, Vol. 59, No. 9, 2006, pp. 1287-1310. doi: $10.1177 / 0018726706069772$

[47] D. Sutton and D. Martin-Jones, "Deleuze Reframed," I. B. Tauris, London, 2008, p. 6.

[48] L. R. Bryant, "Difference and Givenness: Deleuze's Transcendental Empiricism and the Ontology of Immanence," Northwestern University Press, Evanston, 2008, p. 58.

[49] G. Deleuze, "Negotiations," Columbia University Press, New York, 1995.

[50] L. Capeheart and D. Milovanovic, "Social Justice: Theories, Issues and Movements," Rutgers University Press, Piscataway, 2007, p. 125.

[51] J. Weinstein, “Introduction Part II," In: C. Colebrook and J Weinstein, Eds., Deleuze and Gender, Edinburgh University Press, Edinburgh, 2008, p. 23.

[52] J. Rajchman, "The Deleuze Connections," MIT Press, London, 2000, p. 153. 